\title{
KPU dan Konsolidasi Demokrasi: Studi Terhadap Independensi KPU Kota Makassar
}

\author{
Alfyana, Fajar \\ Program Studi Ilmu Politik UIN Alauddin Makassar
}

\begin{abstract}
Abstrak
Artikel ini akan membahas tentang konsolidasi demokrasi di Makassar. Dengan Kajian utama pada kasus Pilwali 2018 di Kota Makassar. Metode penelitian yang digunakan dalam penelitian ini adalah metode penelitian kualitatif dengan tipe penelitian deskriptif analisis. Dalam penelitian ini menggunakan teori demokrasi, strukturasi serta konsep independensi. Temuan penelitian, pertama, dalam verifikasi berkas paslon bahwa KPU berdasar pada peraturan No.3 Tahun 2018 tentang acuan memverifikasi berkas yang dimana meliputi verifikasi administrasi dan verifikasi faktual. Kedua, dalam penetapan paslon bahwa KPU melakukan verifikasi berkas calon dengan meninjau langsung kesesuaian ijazah mulai dari sekolah pertamanya sampai pendidikan terakhirnya dan KPU juga memastikan apakah paslon telah melaporkan harta kekayaannya kepada KPK dengan berdasar pada UU No.10 Tahun 2016 maka paslon telah resmi ditetapkan. Ketiga, dalam diskualifikasi paslon KPU tidak memiliki otoritas dan menghiraukan putusan bawaslu sehingga terjadi diskualifikasi yang seharusnya KPU tidak perlu mendengar putusan PTTUN dan mengajukan kasasi ke MA karena putusan bawaslu juga sesuai dengan aturan perundang-undangan. Keempat, dalam proses pemungutan suara KPU membentuk KPPS yang bertugas di TPS untuk melaksanakan pemugutan suara. Dalam hal ini KPU hanya memfasilitasi kandidat dan pemilih bukan melakukan mobilisasi apalagi intervensi kepada pemilih. Kelima, dalam penetapan hasil pemungutan suara KPU melakukan rekap atau hasil perhitungan secara transparan ke masyarakat, KPPS sampai kecamatan dan terakhir rekap di KPU.
\end{abstract}

Kata Kunci :

Pemilu, Independensi KPU, Demokrasi

\section{PENDAHULUAN}

Dalam kontestasi Pilwali Kota Makassar yang berlangsung tahun ini, begitu sangat menarik perhatian publik. Karena pada tahun 2018 ini peserta yang resmi mendaftar dan ikut dalam kontestasi politik hanya diikuti pasangan calon tunggal melawan kotak kosong. Sebelum kotak kosong menjadi pesaing Appi-Cicu,
Pilwali Makassar juga diikuti oleh pasangan petahana Mohammad Ramdhan Pomanto-Indira Mulyasari Pramusti (Diami). Pasangan ini maju melalui jalur independen. Namun, pasangan ini didiskualifikasi KPU sehingga kontestasi Pilwali di Makassar hanya diikuti oleh pasangan calon tunggal. 
Sebagai lembaga yang lahir dari Rahim undang-undang, KPU menjadi sebuah lembaga yang memiliki otoritas dalam menjalankan amanat UU sebagai penyelenggara pemilihan umum baik di tingkat nasional atau daerah. Mekanisme proses penyelenggara pun diatur secara terperinci oleh UU Pemilu. Sebagai penyelenggara pemilu atau Pilkada, KPU sering menjadi sorotan publik, bukan karena kewenangannya yang dilegitimasi UU melainkan integritasnya dalam memproses perhitungan suara. Keputusan KPU sering sekali menjadi polemik bagi para peserta calon apalagi mereka yang "gugur" dalam pertarungan, dan yang menjadi sasaran utama yakni KPU untuk memberikan klarifikasi atas keputusan yang dihasilkannya.

Kasus sengketa Pilkada sangat masif terjadi di setiap daerah, segala bentuk protes hingga penyerangan terhadap kantor KPU tidak dapat dibendung. Kasus pertama, yang masih hangat yakni Pilkada Kabupaten Gowa 2016 lalu yang sampai menjadi isu nasional dengan tudingan bahwa KPU tidak netral dan diduga berpihak kepada salah satu pasangan calon. Anarkisme pun tidak dapat dibendung, kantor KPU dan DPR menjadi sasaran amuk oleh salah satu tim sukses yang tidak menerima hasil perhitungan KPU. Walaupun pada akhirnya dapat diselesaikan.

Kasus kedua, yang terjadi di Papua, dimana seorang caleg membeli 50 lembar kertas suara seharga Rp 15 juta. Bila dianalogikan dengan praktik jual beli secara umum, bisa dikatakan bahwa komoditas kertas suara ini dijual dalam bentuk grosir: caleg terima beres karena secara langsung, petugas KPPS dan timnya yang melakukan pencoblosan tersebut. Ada juga caleg yang bisa memperolehnya dengan harga Rp 10 juta, dengan jumlah kertas suara yang sama di kelurahan lain. Selain itu, ada caleg yang membeli kertas suara secara eceran seharga Rp 50 ribu per lembar dan mesti membayar Rp 50 ribu untuk tiap orang yang mencobloskan satu kertas suara. ${ }^{1}$

Kasus ketiga, yang sudah menjadi rahasia umum, dan hampir merata di seluruh daerah yakni, membeli suara ke PPS, PPK dan KPU Kabupaten/kota. Modus ini melibatkan secara sepihak penyelenggara pemilu ini bisa lebih efektif dan simple dalam pergeseran suara sehingga lebih diminati oleh caleg dalam praktik vote trading. Dalam praktik vote trading tersebut, sangat mungkin terjadi transaksi antara oknum calon DPR/DPRD dengan oknum penyelenggara pemilu di semua tingkatkan, tanpa melibatkan para caleg yang kalah, yang suaranya dipindahkan. Karena para caleg yang potensial tidak terpilih cenderung mengabaikan perolehan suaranya. $^{2}$

Ketiga kasuistik diatas, sangat kontra produktif dengan spirit demokrasi bangsa ini. dan mencederai prinsip atau nilai keislaman sendiri yang menyeruh

${ }^{1}$ Edward Aspinall \& Mada Sukmajati, Politik Uang di Indonesia, (Yogyakarta: Polgov, 2015), h. 502. 
ummatnya untuk berlaku adil. Sebagaimana firman Allah Swt dalam Q.S Al Maidah/5: $8{ }^{3}$ Ayat tersebut memerintahkan manusia untuk selalu berbuat adil. Karena perbuatan adil dekat dengan ketaqwaan seseorang kepada penciptaNya. Begitu pula yang seharusnya dilakukan pihak penyelenggara yakni KPU untuk tetap independen dan menjaga netralitas sebagai penyelenggra. Agar terciptanya demokrasi yang substansial yang tidak hanya sebatas seremoni. Sehingga harapan masyarakat untuk mendapatkan pemimpin yang bermoral, berintegritas dan memiliki kapabilitas dapat terwujud.

Bagi peneliti, jika Pilkada selalu diwarnai konflik karena ketidakpercayaan publik atas penyelenggara yakni KPU terus berlanjut, maka hal ini sangat mencederai model pemerintahan Negara ini yang menganut sistem demokrasi. Sehingga demokrasi hanya dipandang sebatas seremoni saja yang berkutat pada kuantitas dan minus kualitas. Namun fokus peneliti bukanlah melihat dinamika partai politik dan Pilkada pada tahun politik kali ini melainkan mencoba "mendeteksi" Independensi KPU sebagai penyelenggara Pilkada di Makassar. Sebagaimana yang dilegitimasi UU. No. 22 Pasal 110 Tahun 2007 tentang Penyelenggaran pemilu terkait kode etik KPU yang mencakup sikap independen, kemandirian, integritas, dan kredibilitas anggota KPU tingkat kota, provinsi, PPK, PPS, KPPS PPLN, dan

\footnotetext{
${ }^{3}$ Kementerian Agama, Al-Qur"an Tajwid dan Terjemahanya, (Bandung: Syaamil AlQur"ean, 2010), h. 108.
}

KPPSLN serta anggota Panwaslu, Bawaslu, pengawas pemilu. ${ }^{4}$ Oleh sebab itu peneliti tertarik untuk mengkaji dan mengelaborasi lebih mendalam terkait masalah tersebut. Dan membuktikan secara detail dengan mengumpulkan datadata serta mendapat informasi yang "shahih" dengan bertabayyun langsung kepada KPU Kota Makassar. Hal ini yang mendorong peneliti untuk melihat lebih jauh tentang bagaimana independensi KPU Kota Makassar dalam proses pemilihan Walikota Makassar tahun 2018?

\section{TINJAUAN PUSTAKA}

Tinjauan Pustaka digunakan sebagai pembeda riset yang akan peneliti lakukan dengan kajian sebelumnya, yang tentunya relevan dengan penelitian peneliti. Bentuknya bisa berupa Tesis, Disertasi, Jurnal, dan Buku. Namun dalam skripsi ini peneliti menemukan lima kajian yang bagi peneliti relevan dengan riset yang akan diteliti. Pertama, sebuah tulisan dari Mohammad Najib yang berjudul Keterlibatan Penyelenggara Pemilu dalam Vote Trading. Pemilu sebagai arena kompetisi untuk memperebutkan kursi kekuasaan tidak luput dari berbagai bentuk kecurangan dan pelanggaran. Kasus yang cukup merusak integritas pemilu adalah "perdagangan suara" oleh oknum penyelenggara pemilu. Dalam praktik seperti ini sangat terpercaya keberhasilannya karena dokumen rekapitulasi perhitungan suara dalam Pilkada hanya

${ }^{4}$ Rozali Abdullah, Mewujudkan Pemilu Yang Lebih Berkualitas, (Jakarta: PT RajaGrafindo Persada, 2009), h. 134. 
melibatkan penyelenggara KPU. ${ }^{5}$ Namun yang membedakan tulisan diatas dengan riset yang akan dilakukan peneliti terletak pada tujuan peneliti yang fokus melihat Independensi lembaga KPU khususnya di Kota Makassar pada Pilwali 2018. Karena bagi peneliti hadirnya beberapa kasus seperti yang dikemukakan sebelumnya terjadi karena tidak adanya integritas dan Independensi dari penyelenggara dalam kontestasi pemilu atau Pilkada.

Kajian kedua, yang dilakukan oleh Ridwan seorang peneliti yang di dalamnya risetnya berjudul Jayapura Utara, Papua: membeli pemilih dan Penyelenggara Pemilu. Para caleg dengan sumber daya yang memadai dapat memilih apakah mereka akan membagi-bagikan uang atau barang kepada para pemilih, atau menggunakan sumber daya tersebut untuk membayar penyelenggara pemilu. Bercermin pada pileg 2014 di Jayapura Utara adalah para caleg dan tim sukses membeli kertas suara sisa dari komite Penyelenggara pemungutan suara (KPPS). Yang dimaksud dengan kertas suara di sini ialah undangan kartu untuk memilih caleg yang diberikan kepada pemilih untuk mencoblos pada hari $H$. Sebagian TPS melalui KPPS-nya sengaja tidak membagikan undangan (kertas suara) tersebut. sebaliknya, kertas tersebut malah dijual ke

\footnotetext{
${ }^{5}$ Mohammad Najib, Keterlibatan Penyelenggara Pemilu dalam Vote Trading, (Yogyakarta: Polgov, 2015), h.511.
}

caleg yang ingin mendapatkan suara lebih. ${ }^{6}$

Kajian ketiga, yang dilakukan oleh Tengku Rika Valentina dengan judul Peluang Demokrasi dan Peta Perilaku Pemilih Terhadap Partai Politik untuk Pemilu 2009 di Yogyakarta. Pemilihan umum diakui secara global sebagai sebuah arena untuk membentuk demokrasi perwakilan serta pergantian pemerintahan secara berkala. Menurut teori demokrasi minimalis yang dikemukakan oleh Schumpetrian, pemilu merupakan sebuah arena yang mewadahi kompetisi (kontestasi) antara aktor politik untuk meraih kekuasaan, partisipasi politik yang membuat rakyat dapat menentukan pilihannya. Tuntutan agar partai politik memegang fungsi kebijakan terasa mengada-ada kalau kita tidak mendudukkan partai politik sebagai esponen dalam sistem pemerintahan yang demokratis. ${ }^{7}$

Kajian keempat, di dalam disertasi Syahabuddin yang berjudul Demokrasi dalam Pandangan Kahar Muzakkar. Bahwa di dalam sebuah kontestasi politik hal yang paling fundamental yang mesti di utamakan yakni sistem demokrasi. Yang dimana rakyat sebagai pemegang kekuasaan, pembuat dan penentu keputusan dan kebijakan tertinggi dalam penyelenggaraan negara dan pemerintahan serta

${ }^{6}$ Ridwan, Jayapura Utara, Papua: Membeli Pemilih dan Penyelenggara Pemilu, (Yogyakarta: Polgov, 2015). h. 486.

${ }^{7}$ Tengku Rika Valentina, "Peluang Demokrasi dan Peta Perilaku Pemilih Terhadap Partai Politikuntuk Pemilu 2009 di Yogyakarta", Jurnal: Demokrasi, Vol. VIII No. 2 (2009), h. 167-186. 
sebagai pengontrol pelaksanaan kebijakannya, baik yang dilakukan secara langsung oleh rakyat atau yang mewakilinya melalui lembaga perwakilan. Karena itu, Negara yang menganut sistem demokrasi diselenggarakan berdasarkan kehendak dan kemauan rakyat mayoritas dan juga tidak mengesampingkan kaum minoritas. ${ }^{8}$

Kajian kelima, dilakukan oleh Syahrul Hidayat di dalam sebuah riset terkait rasionalitas politik pemilih miskin di Surabaya dan Jakarta. Di dalam riset tersebut menemukan beberapa kemungkinan terjadinya praktik-praktik mobilisasi di dalam masyarakat miskin perkotaan. Dari perdebatan mengenai money politic, akan diungkap berapa banyakkah sebenarnya segmen masyarakat miskin yang terkena praktik itu dan bagaimana sikap masyarakat miskin menghadapinya. ${ }^{9}$ Namun berbeda dengan yang akan diteliti oleh penulis, yakni lebih melihat KPU sebagai penyelenggara dalam mengatur mekanisme pemilu dengan independen.

Dari pertama hingga kelima kajian diatas lebih fokus kepada setiap pelanggaran yang dilakukan oleh penyelenggara yakni KPU yang terjadi di lima daerah yang berbeda. Namun yang membedakan dengan karya yang akan diteliti oleh peneliti terletak pada objeknya peneliti lebih memfokuskan pada lembaganya

\footnotetext{
${ }^{8}$ Syahabuddin, "Demokrasi dalam Pandangan Abdul Kahar Muzakkar", Program Pasca Sarjana UIN Sunan Kalijaga, Disertasi (Yogyakarta: Program Pascasarjana UIN Sunan Kalijaga, 2006).

${ }^{9}$ Syahrul Hidayat, Rasionalitas Politik Pemilih Miskin: Dari Survey di Jakarta dan Surabaya, (Jakarta: FISIP UI, 2000), h. 82.
}

dengan menelisik Independensi KPU dalam kontestasi Pilwali Kota Makassar. Sehingga tidak ada upaya pelanggaran pemilu yang masif terjadi dengan segala modus dapat dihindari. Tentunya dengan menghadirkan independensi serta integritas KPU dalam "panitia" Pilwali Kota Makassar.

\section{TINJAUAN TEORI}

Sistem politik Indonesia, demokrasi menjadi salah satu "alat" terbaik yang digunakan di Indonesia dalam sebuah pemilihan umum. Demokrasi pula sering disebut sistem pemilihan langsung. Dimana masyarakat langsung memberikan hak suaranya dengan mencontreng atau mencoblos calon peserta pemilu di dalam kotak suara yang telah disediakan penyelenggara pemilu yakni KPU. Di dalam sebuah "hajatan" setiap lima tahun sekali menjadi hak fundamental KPU dalam mempersiapkan "arena" kontestasi politik sebuah negara atau kota dan kabupaten.

Dalam menjalankan amanat UU. No. 22 Pasal 110 Tahun 2007 KPU dituntut agar bersikap independen dalam menyelenggarakan sebuah pemilu. Independensi KPU menjadi "ruh" sebagai penyelenggara pemilu. Karena tidak sedikit Pilkada yang ditemukan di beberapa daerah di Indonesia berakhir di meja Mahkamah Konstitusi. Hal tersebut terjadi karena ketidakpuasan salah satu pasangan calon terhadap keputusan KPU yang diduga tidak bersikap independen, dengan memihak salah satu pasangan calon 
peserta Pilkada. Jika hal itu benar terjadi maka secara tidak langsung telah mencederai proses berdemokrasi sekaligus kontra produktif dengan spirit demokrasi.

Dalam mengelaborasi persoalan Pilwali tahun 2018 ini, peneliti melihat sebuah "pengingkaran" terhadap nilai luhur demokrasi. Oleh karena itu, peneliti akan menggambarkan skema pemetaan yang berkorelasi terhadap tujuan penelitian ini yang berangkat dari sebuah paradigma integrasi-interkoneksi, yakni adanya keselarasan antara teks dan konteks, yakni UU. No. 22 Pasal 110 Tahun 2007 terkait Independensi KPU yang bersifat normatif.

Secara konseptual dalam penelitian ini terdapat dua variabel yakni KPUD dan konsolidasi demokrasi dalam kontestasi politik pemilihan Walikota 2018. Dalam menjelaskan hubungan kedua variable tersebut peneliti menggunakan teori yang sesuai dengan objek tersebut. Pertama, peneliti menggunakan teori David Baetham dan Kevin Boyle tentang demokrasi. ${ }^{10}$ Bagi peneliti, teori tersebut sesuai dan relevan dengan objek yang akan diteliti. Dengan teori yang dikemukakan David Baetham dan Boyle ini peneliti akan mengelaborasinya sesuai dengan kontestasi pemilihan Walikota Makassar yang secara spesifik menakar sejauhmana ukurun demokratisasi pada kontestasi Pilwali Makassar 2018. Kedua, peneliti menggunakan teori Antonio

\footnotetext{
${ }^{10}$ Lihat Muslim Mufti, Teori-Teori Politik, (Bandung: Pustaka Setia, 2012).
}

Giddens tentang strukturasi. ${ }^{11}$ Di mana peneliti ingin melihat korelasi antara struktur atau sistem yang peneliti mengandaikannya menjadi KPU dan agen yakni masyarakat Makassar dalam kontestasi Pilwali Makassar. Sehingga partisipatif dan respon masyarakat Kota Makassar dalam mengkomunikasikan informasi, pandangan-pandangan, mampu mengekspresikan sikap-sikap positif dan negatifnya kepada KPU sebagai struktur (penyelenggara). Dalam hal ini masyarakat harus aktif menyuarakan masalah-masalah yang ada, dengan mendeteksi dan mengidentifikasi persoalan-persoalan serta mampu menawarkan solusi-solusi dan mendramatisir segala masalah tersebut.

\section{METODE PENELITIAN}

Penelitian ini adalah bersifat deskriptif karena bertujuan untuk memahami dinamika KPU sebagai lembaga yang memiliki otoritas untuk menyelenggarakan pemilu. Menggunakan metode pengumpulan data yang digunakan dalam penelitian, wawancara serta studi literatur. Adapun objek penelitian ini melihat independensi KPU Makassar sebagai penyelenggara Pilwali Makassar dan menakar konsolidasi demokrasi Makassar pasca putusan PT-TUN terkait pembatalan pencalonan Danny Pomanto dan Indira sebagai peserta calon Pilwali Kota Makassar 2018. Dalam menganalisis

\footnotetext{
${ }^{11}$ Baca Irvan Januta, "Teori Strukturasi Anthony Giddens", Tesis (Yogyakarta: UIN Sunan Kalijaga, 2003). Baca juga Pip Jones, Pengantar Teori-Teori Sosial dari Teori Fungsionalisme hingga Post Modernism, (Jakarta: Yayasan Pustaka Obor Indonesia, 2009), h. 240.
} 
persoalan Pilwali Kota Makassar di atas, selain menggunakan sejumlah teori, penulis pun menggunakan pendekatan dalam riset ini. Dalam hal ini penulis menggunakan pendekatan feno-menologis. Dengan melihat kondisi politik, sosial di dalam kontestasi Pilwali Makassar. Dengan melakukan interview (wawancara) kepada pihak-pihak yang memiliki kapabilitas atau basis keilmuan terkait KPU dan demokrasi secara mendalam. ${ }^{12}$

Dalam hal observasi peneliti berusaha menghadiri seminar atau diskusi yang berkaitan dengan KPU dan Pilkada. Sementara dokumentasi dilakukan dengan memotret kegiatan-kegiatan yang bersinggungan dengan riset yang dilakukan peneliti serta berfoto dengan para informan sebagai bukti empirik.

\section{PEMBAHASAN}

\section{Analisis Independensi KPU dalam} Kontestasi Pilwali Kota Makassar

Komisi Pemilihan Umum adalah lembaga negara yang lahir dari rahim konstitusi UUD yang bertugas sebagai penyelenggara pemilihan umum. Amanat konstitusi melegitimasi KPU sebagai lembaga independen. Dalam konteks pemilihan walikota Makassar.KPU Makassar di uji netralitasnya. Oleh karenanya dalam penelitian ini, penulis ingin mengetahui netralitas KPU Makassar dalam Pilwali 2018. Dengan melihat beberapa aspek

\footnotetext{
${ }^{12}$ Sukmadinata, Metode Penelitian, (Bandung: Rosdakarya, 2006), h. 53.
}

yang merupakan substansi dari pekerjaan KPU. Diantaranya:

\section{Independensi KPU dalam Verifikasi} Berkas Pasangan Calon

Untuk menakar sejauh mana netralitas KPU Makassar dalam pemilihan Walikota Makassar 2018. Dapat dilihat dari proses verifikasi berkas pasangan kandidat. Sebagaimana yang dikatakan oleh komisioner KPU Makassar bahwa:

"Dalam memverifikasi, regulasi yang mengatur yaitu Peraturan KPU No. 3 Tahun 2018 (pen, acuan memverifikasi berkas). Paslon yang ada di Pilwali ada dua paslon, ada paslon yang maju melalui jalur perseorangan dan paslon yang maju melalui dukungan partai politik (usungan partai politik). Berkas calon yang maju melalui jalur perseorangan yang diverifikasi berkas dukungannya yaitu, KTP (foto kopi KTP) dari para pendukung. Jadi paslon harus didukung oleh sekian jumlah pendukung yang mendukungnya. Misalnya, dalam regulasi diatur bahwa jika jumlah pendukungnya diatas 1 juta, maka harus minimal didukung 6,5\% dari jumlah DPT. Jadi apabila 1 juta berkas DPT itu harus didukung 6,5\% DPT terakhir Kota Makassar sebelum Pilkada 1 juta 5 ribu, berarti jika 6,5\% dari 1 juta itu 65.000. Jadi 65.000 itulah minimal yang harus disetor dukungannya berupa foto kopi KTP masyarakat yang dikumpulkan oleh pasangan calon yang maju melalui jalur perseorangan. Setelah mereka memasukkan dukungan KTPnya, pihak KPU menghitung pada verifikasinya yaitu, 
verifikasi administrasi dan verifikasi faktual. Jadi pihak KPU melakukan verifikasisebanyak dua kali. Pertama, memeriksa administrasinya apakah jumlah dukungannya mencapai 65ribu yang mereka kumpulkan. Tapi ternyata mereka mengumpulkan sekitar 130 ribu lebih. Jadi paslon Danny-Indira itu memasukkan 130 ribu lembar dukungan, jadi jumlah tersebut yang di verifikasi oleh KPU. Diverifikasi administrasi terlebih dahulu mana yang memenuhi syarat dan mana yang tidak memenuhi syarat. Setelah pihak KPU melakukan verifikasi administrasi, maka tersisa 125 ribu. Jadi 125 ribu itulah yang dinyatakan lolos verifikasi berkas. Lalu kemudian dilakukan verifikasi faktual, verifikasi faktual artinya pihak KPU turun ke lapangan menanyakan ke semua yang punya KTP apakah betul warga ini mendukung atau tidak. Setelah KPU melakukan verifikasi faktual, kemudian dari 125 ribu itu menjadi 119 ribu. Nah 119 ribu inilah yang KPU terima sebagai berkas dukungan dari pasangan calon yang maju melalui jalur perseorangan (Danny-Indira). Persyaratan yang harus dipenuhi yaitu 6,5\% atau 65.354 itu minimalnya sedangkan DIAmi memasukkan 119 ribu maka itu sudah melebihi dari batas minimal yang telah ditentukan. Berarti pasangan DIAmi sudah memenuhi syarat (pen,itulah yang dipersyaratkan oleh UU)."13

Sebagaimana yang dituturkan komisioner KPU di atas menuturkan bahwa dalam

\footnotetext{
${ }^{13}$ Abdullah Mansur, Komisioner KPU Makassar, wawancara pada tanggal 29 Oktober 2018.
}

proses verifikasi yang dilakukan KPU melalui dua tahap yakni verifikasi secara administrasi dan faktual. Dalam hal ini dilakukan pada calon Walikota yang melalui jalur independen yang harus mengumpulkan kartu tanda penduduk (KTP) masyarakat Makassar. Sebagaimana aturan PKPU yang mengatur jumlah foto copy yang harus dikumpulkan. Dua tahap menyeleksi KTP dalam hal administrasi dilakukan KPU untuk melihat keaslian KTP yang dikumpulkan. Sedangkan tahap faktual KPU turun ke lapangan untuk meninjau masyarakat yang telah mengumpulkan KTP. Untuk menanyakan kebenaran dukungannya terhadap pasangan calon. Namun tidak hanya melalui kedua tahap tersebut. Untuk lebih meyakinkan bahwa independensi KPU dalam verifikasi berkas. KPU juga melibatkan panwaslu.

"Indepensinya yaitu pada saat melakukan verifikasi ada panwas yang menyaksikan, apakah betul atau tidak cara verifikasi yang dilakukan oleh KPU dan juga ada tim masing-masing paslon yang mengawasi pihak KPU. Jadi, betul-betul tidak ada yang salah dalam proses verifikasi. Itulah ukuran independensinya KPU dengan melibatkan semua pihak untuk menyaksikan proses verifikasi secara transparan (pen,itu untuk calon perseorangan).,"14

Terlibatnya panitia pengawas pemilu (panwaslu) dalam proses verifikasi berkas

\footnotetext{
${ }^{14}$ Abdullah Mansur, Komisioner KPU Makassar, wawancara pada tanggal 29 Oktober 2018.
} 
semakin menguatkan kredibilitas KPU sebagai lembaga penyelenggara. Bahwa KPU bekerja sesuai aturan yang telah diatur oleh Undang Undang. Sedangkan dalam memverifikasi berkas pasangan calon yang melalui partai pengusung juga telah diatur di dalam Undang-Undang. Sebagaimana yang dikatakan bahwa:

"Untuk calon yang maju melalui usungan parpol, dalam regulasi disebutkan dalam UU No.10 Tahun 2016 Peraturan KPU No. 3 Tahun 2018 disebutkan bahwa calon yang maju melalui usungan parpol itu harus diusung minimal $20 \%$ dari jumlah kursi di DPRD Kota Makassar sehingga Partai Politik atau Gabungan Partai Politik dalam mengajukan pasangan calon Walikota dan Wakil Walikota Makassar sedikitnya memenuhi 10 (Sepuluh) Kursi di DPRD Kota Makassar. Sedangkan di Kota Makassar itu ada 50 (Lima puluh) jumlah kursi di dewan. 20\% dari $50 \%$ itu 10\% berarti minimal 10 (sepuluh) kursi yang harus dikumpulkan. Lalu pasangan yang maju melalui usungan partai politik yaitu pasangan Appi-Cicu yang diusung oleh 10 partai politik yang ada di Kota Makassar. Tetapi mines di partai Demokrat karena 12 parpol yang ada di Makassar pada waktu itu, namun 1 partai yang tidak dapat kursi di dewan yaitu PKB. Jadi tinggal 11 parpol, dari 11 parpol ini 10 parpol yang mengusung Appi-Cicu kecuali partai Demokrat yang tidak mendukung. Partai Demokrat di dewan kursinya 7 berarti 50-7 sama dengan 43 kursi jadi, Appi-Cicu didukung sekitar 43 kursi. Jika 43 kursi sedangkan persyaratan minimalnya 10 kursi artinya sudah memenuhi syarat itu verifikasinya. Nah verifikasi tersebut juga dilakukan secara transparan dan disaksikan oleh panwas (pen,verifikasi secara transparan).",15

Setelah melihat pendapat komisioner KPU diatas, dengan secara seksama maka dapat disimpulkan bahwa dalam proses memverifikasi berkas pasangan calon yang melalui jalur independen maupun partai pengusung telah diatur di dalam UndangUndang. KPU hanya mengimplementasikan apa yang diletigimasikan oleh Undang-Undang. Oleh karenanya, proses verifikasi yang dilakukan KPU Makassar dalam pemilihan Walikota Makassar dapat dikatakan telah melalui prosedur dan mekanisme yang telah diatur sebelumnya di dalam Undang-Undang. Sehingga dapat disimpulkan bahwa KPU Makassar independen dalam memverifikasi berkas pasangan calon

Dari sisi normatifnya mekanisme verifykasi berkas yang dilakukan KPU diatas, telah sesuai aturan Undang-Undang pemilu. Namun ada catatan kecil penulis jika melihat proses verifikasi berkas tersebut dari sisi praktis. Pertama, proses pengumpulan kandidat yang mengunakan KTP, besar kemungkinan adanya "pembeliaan" foto copy KTP yang dilakukan Timses yang menggerakkan ketua RT dalam menjalankan aksinya. Kedua, indikasi "transaksi" foto copy KTP dapat terjadi di Disdukcapil. Apalagi yang

\footnotetext{
${ }^{15}$ Abdullah Mansur, Komisioner KPU Makassar, wawancara pada tanggal 29 Oktober 2018.
} 
bertarung kembali adalah petahana. Ketiga, calon yang diusung oleh partai politik pula mengalami kondisi serupa, pragmatisme menjadi tidak dapat dihindarkan sehingga penantang yakni (Appi-Cicu) memborong partai politik yang ada dengan melakukan lobi di DPP. Hanya untuk meraup dukungan suara partai politik. Akan tetapi, suara partai politik hanya mengantarkan paslon pada syarat pencalonan. Dan tidak memberikan jaminan pada kemenangan kandidat. Karena kemenangan hanya ditentukan seberapa kuatnya mesin partai bergerak.

\section{Independensi KPU dalam Penetapan Pasangan Calon}

Selain proses verifikasi berkas yang dilakukan KPU, maka tahap selanjutnya adalah penetapan pasangan calon. Dalam menentukan pasangan calon KPU kembali melakukan verifikasi calon. Berbeda pada tahap sebelumnya yang masuk dalam verifikasi pencalonan. Dalam tahap verifikasi penetapan calon ini. KPU melakukan sejumlah seleksi yang ketat. Dengan mencocokkan ijazah yang dimiliki kandidat. Sebagaimana penuturan anggota KPU, bahwa:

"Setelah berkas administrasi yang telah diverifikasi dan telah memenuhi syarat nah itulah kemudian yang 119 ribu itu dilakukan verifikasi kembali apakah betul semua ini. Maka mereka semua sudah bisa melakukan pendaftaran, yah kita verifikasi kembali berkas calonnya karena yang diverifikasi pertama itu berkas pencalonan. Karena ada dua verifikasi berkas pertama verifikasi berkas pencalonan dan yang kedua verifikasi berkas calon.Jadi ketika mendaftar mereka melakukan dua kali verifikasi yaitu verifikasi berkas pencalonan itu yang berupa syarat dukungan dan verifikasi berkas calon itu satu per satu calonnya dilakukan verifikasi seperti ijazah seтиa calon diperiksa mulai dari ijazah bahwa sekolah pertamanya sampai pendidikan terakhirnya seperti mendatangi sekolah-nya apakah betul calon ini pernah sekolah di sekolah yang tertera pada ijazahnya. jadi semua paslon itu diteliti berkasnya jadi betul-betul detail proses verifikasi berkas calonnya. Dan juga diperiksa apakah sudah melapor-kan harta kekayaannya ke KPK apakah betul laporan calon tersebut. Ada pernyataan dari KPK bahwa sudah melaporkan kekayaannya setelah diangg- ap seтиa sudah memenuhi syarat, syarat pencalonan dan syarat calonmaka menurut Peraturan KPU No. 3 Tahun 2018 dan UU No. 10 Tahun 2016 itu sudah bisa ditetapkan sebagai pasangan calon maka itulah yang kami tetapkan." 16

Sebagaimana penuturan komisioner KPU diatas, bahwa dalam penetapan kandidat pasangan calon melalui seleksi yang begitu ketat. Bahkan KPU meninjau langsung sekolah dan universitas kandidat. Hal tersebut dilakukan agar menyakinkan bahwa ijazah para pasangan calon adalah ijazah asli yang benar adanya dikeluarkan pihak sekolah dan universitas. Namun bukan hanya sekedar peninjauan langsung yang dilakukan KPU. Melainkan para

\footnotetext{
${ }^{16}$ Abdullah Mansur, Komisioner KPU
} Makassar, wawancara pada tanggal 29 Oktober 2018. 
kandidat harus pula memberikan laporan kekayaan hartanya kepada komisi pemberantasan korupsi (KPK). Maka dapat dikatakan ukuran dari independennya KPU dalam penetapan calon dapat dilihat dari KPU menjalankan segala regulasi yang telah diatur. Dan tentunya KPU tidak dapat di intervensi oleh pihak manapun Pasca verifikasi KPU akan melakukan penetapan pasangan calon yang telah lulus seleksi berkas. Dalam penetapan pasangan calon sebelumnya. Komisioner KPU telah menjelaskan diatas, akan tetapi proses penetapan bisa saja terindikasi tidak netral jika salah satu prosedur dalam penetapan dilanggar oleh KPU.

\section{Independensi KPU pada Saat} Diskualifikasi Pasangan Calon

Dalam pemilihan Walikota Makassar tahun 2018, berhasil menarik perhatian publik. Bukan hanya masyarakat Makassar bahkan tingkat nasional. Dikarenakan terjadinya diskualifikasi terhadap salah satu calon Walikota yang diduga ketika itu melakukan pelanggaran. Karena memanfaatkan jabatannya sebagai Walikota untuk mengambil start kampanye terlebih dahulu. Penantang pun dengan segera melaporkan pelanggaran tersebut dengan agar petahana dapat di diskualifikasi dari pemilihan Walikota Makassar. Laporan yang dilakukan pihak penantang ke panwaslu, ternyata tidak berhasil menyakinkan panwaslu. Sehingga petahana masih dapat mencalonkan dirinya sebagai calon walikota. Namun langkah tersebut tidak membuat penantang (AppiCicu) putus asa.
Gagalnya di panwaslu membuat penantang kembali membawanya ke PTTUN hingga putusan akhirnya ditetapkan oleh Mahkamah Agung (MA) yang menetapkan terdiskualifikasinya petahana dalam pesta demokrasi 2018 di Makaasar, sebagaimana yang dikatakan salah seorang komisioner bidang tekhnisi KPU Makassar bahwa:

"Kenapa kita mendiskualifikasi, karena itu putusan Mahkamah Agung jadi asal mulanya seperti ini, kami telah menetapkan dua pasangan calon yaitu Danny-Indira dan Appi-Cicu. Sudah dilakukan penetapan pasangan calon serta pengundian nomor urut, maka pasangan nomor urut 1 itu mengajukan gugatannya ke PANWAS Kota Makassar karena menganggap bahwa penetapan KPU ini salah. Seharusnya KPU tidak menerima berkas calon dan berkas pencalonan pasangan Danny-Indira karena pasangan tersebut melanggar sehingga pasangan Appi-Cicu memasukkan gugatan ke Panwas lalu disidanglah di Panwas. Alasan pasangan Danny-Indira digugat oleh pasangan Appi-Cicu karena telah melanggar UU No. 10 Tahun 2016 pasal 71 ayat 2 dan 3 tentang penggunaan kewenangan petahana.Setelah sidang di panwas, melalui yang namanya Musyawarah Penyelesaian Sengketa (MPS) di Panwas dan dihadirkan saksi, ahli, Panwas memutuskan bahwah menolak gugatan Appi-Cicu. Artinya, pasangan calon Danny-Indira tetap bisa ikut bertarung di Pilwali 2018 tidak di diskualifikasi.Nah, pasangan Appi-Cicu tidak puas dengan keputusan Panwas, dan 
karena memang dibolehkan oleh regulasi maka pasangan Appi-Cicu mengajukan lagi gugatan ke PTTUN, kenapa ke PTTUN padahal jenjang peradilan sebelum PTTUN itu ada yang namanya PTUN. Akan tetapi dalam regulasi, untuk persoalan Pilkada itu tidak melalui PTUN lagi tapi langsung ke PTTUN. Jadi mereka memasukkan gugatan ke PTTUN karena pasangan Appi-Cicu tidak puas dengan putusan panwas.

Diterimanya, gugatan pihak penantang oleh PTTUN, bahwa petahana (DannyIndira) harus di diskualifikasi dari Pilwali 2018 Makassar. Namun hal ini pula yang membuat KPU harus bertindak dalam penyelesaian perkara Pilwali. KPU yang juga memiliki otoritas dalam penyelenggaraan pemilu akhirnya bertindak dengan membawa perkara ini ke Mahkamah Agung (MA). Sebagaimana penuturan lanjutan diatas, bahwa:

"Gugatannya sama, meminta diskualifikasi pasangan Danny-Indira dan juga alasan yang sama bahwa melanggar UU No. 10 Tahun 2016 pasca 71 ayat 2 dan3. Di PTTUN gugatan pasangan Appi-Cicu diterima dan PTTUN memerintahkan ke KPU Makassar untuk mendiskualifikasi pasangan Danny-Indira. Karena KPU Makassar merasa apa yang telah diputuskan oleh PTTUN itu sudah benar dan sudah sesuai dengan regulasi, maka dalam regulasi itu juga dibuka ruang untuk KPU Makassar untuk melakukan

\footnotetext{
${ }^{17}$ Abdullah Mansur, Komisioner KPU Makassar, wawancara pada tanggal 29 Oktober 2018.
}

perlawanan. Kami melakukan perlawanan kami juga melakukan kasasi di Mahkamah Agung. Mahkamah Agung menguatkan putusan PTTUN dan akhirnya ketika MA menguatkan putusan PTTUN maka KPU Makassar harus mendiskualifikasi pasangan Danny-Indira. Jadi pasangan calon tersebut di diskualifikasi karena perintah MA. ${ }^{, 18}$

Setelah melalui mekanisme yang telah diatur, maka dalam proses diskualifikasi yang tertuju pada pihak petahana telah resmi dinyatakan gugur sebelum bertanding. Dan tidak dapat ikut serta dalam pesta demokrasi sebagai kandidat, akan tetapi masih dapat menjadi pemilih. Keputusan Mahkamah Agung yang mengikat secara hukum. Menjadi mimpi buruk bagi petahana dan sejumlah team sukses serta para pendukungnya karena gagal ikut mewarnai kontestasi Pilwali Kota Makassar. Karena telah terbukti melakukan pelanggaran sebagaimana yang diatur dalam UU No. 10 tahun 2016 pasal 71 ayat 2 dan 3 . Terkait penyalahgunaan wewenang. Dengan melakukan, pembagian HP ke RT/RW, pengangkatan tenaga honorer, dan penggunaan tag line "Dua kalitambah Baik". Hingga atas legitimasi MA. KPU akhirnya mendiskualifikasi pasangan Danny-Indira sebagai calon Walikota Makassar.

Ukuran independennya KPU dalam proses diskualifikasi calon dapat dilihat dari

\footnotetext{
${ }^{18}$ Abdullah Mansur, Komisioner KPU Makassar, wawancara pada tanggal 29 Oktober 2018.
} 
penuturan komisioner KPU Kota Makassar yang menyatakan bahwa:

"Karena independen kami tidak diintervensi oleh siapapun karena seandainya kami diintervensi maka dari awal kami sudah menerima putusan PTTUN. Kami punya dua putusan pasangan calon tetapi di gugat oleh pasangan Appi-Cicu kemudian di PTTUN, di Panwas kami menang artinya masih tetap dua pasangan calon. Kemudian gugatan masuk di PTTUN kami kalah harusnya paslon Danny-Indira tidak didiskualifikasi lalu kami melakukan perlawanan karena kami anggap bahwa sudah betul tapi ternyata MA menguatkan putusan PTTUN dan kami tidak bisa berbuat apa-apa karena di negara kita ini lembaga peradilan tertinggi itu adalah MA tidak ada lagi diatasnya. Maka mau tidak mau putusan MA harus dijalankan yaitu mendiskualifikasi pasangan DannyIndira. $" 19$

Sebagaimana penyampaian komisioner KPU diatas, maka dapat disimpulkan bahwa dalam proses diskualifikasi pasangan calon walikota Makassar begitu ambigu. Seolah nampak adanya "Main mata" atau keberpihakan KPU kepada salah seorang pasangan calon yang dibungkus rapi seolah-olah proses diskualifikasi yang terjadi benar telah melalui prosedur hukum yang jujur dan transparan. Bagi penulis, KPU tidak perlu melakukan kasasi hingga Mahkamah

\footnotetext{
${ }^{19}$ Abdullah Mansur, Komisioner KPU Makassar, wawancara pada tanggal 29 Oktober 2018.
}

Agung karena putusan dari bawaslu telah sangat mengikat yang dilegitimasi oleh UU. Yang menyatakan bahwa tidak terdapatnya indikasi penyalahgunaan wewenang yang dilakukan petahana. Bukan Cuma hal itu, nampak juga bahwa komisioner KPU tidak sama sekali memiliki otoritas dalam mengambil keputusan dan pertimbangan yang serius. Sehingga menyebabkan anggaran 60 Miliar terbuang percuma. Oleh karena itu, netralitas KPU Kota Makassar dalam proses diskualifikasi dapat dikatakan KPU Kota Makassar telah "bermain mata" dengan salah satu pasangan calon.

\section{Independensi KPU dalam Proses Pemungutan Suara}

Hari H selalu identik dan dikaitkan dengan peristiwa yang sedang berlangsung pada hari tersebut. Dalam konteks pemilu hari H menjadi hari "sakral" yang dinanti para peserta dan penyelenggara pemilu. Seluruh perangkat penyelenggara dimulai dari KPPS, PPS, PPK dan KPU mengambil masingmasing tugasnya. Sejak dimulai pemugutan suara hingga pada perhitungan suara. Melalui beberapa proses tahapan perhitungan. Pada wilayah pemugutan inilah merupakan situasi yang "sensitif". Karena kecurangan seringkali terjadi di proses pemugutan suara. Misalnya, jika pihak KPPS telah melakukan "main mata" terhadap salah satu tim sukses kandidat dengan membeli surat suara sisa. Selain itu, seringpula terjadi surat suara yang digunakan pihak lain. Begitu pula yang terjadi di PPS, PPK bahkan KPU sendiri yang dapat mengganti jumlah suara. Menepis tuduhan yang sering ditujukan 
oleh pihak KPU dan bawahannya atas indenpendensinya. Maka secara tegas Komisioner KPU Makassar membantah segala gosip tersebut dengan mengatakan bahwa:

"Karena pada saat pemungutan suara KPU tidak mengintervensi masyarakat untuk memilih salah satu calon. KPU hanya memfasilitasi proses jalannya pemilu. $" 20$

Penjelasan yang sangat singkat oleh bapak Mansur selaku komisioner setidaknya memberikan informasi terkait independensi KPU Kota Makassar sebagai wasit dalam kontestasi pemilihan Walikota tahun lalu.

\section{Independensi KPU dalam Penetapan Hasil Pemungutan Suara}

Setelah sejumlah rangkaian dan dinamika selama perhelatan pemilihan walikota yang dilalui KPU. Dan bertindak sebagai "wasit" yang adil sebagaimana legitimasi Undang-Undang. Kini memasuki tahapan akhir kontestasi Pilwali 2018 ini. Yakni penetapan hasil pemungutan suara. Dalam tahap akhir ini merupakan "ujian berat" bagi KPU atas netralitas KPU sebagai penyelenggara pemilu. Mulai pembentukan panitia KPPS hingga rekapitulasi suara di KPU kota. Hal itu pula yang diungkapkan oleh Komisioner KPU bahwa

"Pemenangnya berdasarkan suara terbanyak. Kemarin cuma satu paslon

\footnotetext{
${ }^{20}$ Abdullah Mansur, Komisioner KPU Makassar, wawancara pada tanggal 29 Oktober 2018.
}

karena satu paslon telah didiskualifikasi. Kemudian dalam PKPU No. 13 Tahun 2018 yang mengatur tentang satu paslon itu kalau ada satu paslon maka untuk menentukan apakah dia bisa duduk atau tidak diatur dalam PKPU No. 13 disebutkan bahwa jika dia sudah bisa memperoleh lebih dari 50\% suara melawan kolom kosong. Nah kemarin hasil rekap atau hasil perhitungan yang secara transparan KPU buka ke masyarakat, rekap di KPPS sampai kecamatan dan terakhir rekap di KPU. Itu secara berjenjang kami lakukan, proses secara transparan orang lihat, orang tahu, orang saksikan dan ternyata pasangan Appi-Cicu tidak sampai $50 \%$ perolehan suaranya.cuman $43 \%$ sementara kolom kosong sampai 57\%. Artinya apa? Tidak ada walikota. Jadi proses penetapan berdasarkan proses rekap berjenjang dari bawah mulai dari tingkat PPS, PPK dan KPU,. ${ }^{21}$

Di dalam proses terakhir dari sebuah pemilihan ini, KPU menjadi benteng terakhir dalam mewujudkan pemilu yang berintegritas dan bermartabat. Netralitas KPU menentukan kualitas pemimpin yang akan memimpin kota Makassar. Mekanisme penetapan pemenang dari Pilwali ditentukan dengan suara terbanyak $50 \%+1$. Olehnya, pesta demokrasi pemilihan walikota Makassar dimenangkan oleh kotak kosong. Yang berarti pemilihan akan digelar kembali pada tahun 2020 mendatang. Untuk mengisi kursi

\footnotetext{
${ }^{21}$ Abdullah Mansur, Komisioner KPU Makassar, wawancara pada tanggal 29 Oktober 2018
} 
kosong di pemerintah kota Makassar, hingga menunggu 2020 menurut UndangUndang bahwasanya otoritas dimiliki oleh kementerian dalam negeri (kemendagri) untuk menunjuk siapa yang layak menempati posisi kursi nomor satu di Kota Makassar.

\section{Indikator Gugatan Pihak Oposisi}

Penggugat Munafri Arifuddin dan Rachmatika Dewi sang penggugat keberatan terhadap keputusan tergugat yang menetapkan Mohammad Ramdhan Pomanto dan Indira Mulyasari sebagai salah satu Pasangan Calon Walikota dan Wakil Walikota pada Pemilihan Walikota dan Wakil Walikota Makassar tahun 2018, karena Mohammad Ramdhan Pomanto yang merupakan Walikota Makassar atau petahana telah menggunakan kewenangan, program dan kegiatan pemerintah Kota Makassar 6 (enam) bulan sebelum tanggal penetapan pasangan calon oleh tergugat yang menguntungkan dirinya atau merugikan penggugat sebagaimana dilarang oleh ketentuan Pasal 71 ayat 3 UU No. 10 Tahun 2016 Pasal 89 ayat 2 PKPU No. 15 Tahun 2017, Terkait penjelasan beberapa pasal diatas terkait PKPU, maka secara yuridis ditemukan beberapa pelanggaran yang dilakukan oleh petahana secara struktural dengan memanfaatkan otoritasnya sebagai Walikota. Diantaranya:

\section{Pembagian HP kepada Ketua RT dan} Ketua RW se-Kota Makassar

Tindakan yang dilakukan oleh Mohammad Ramdhan Pomanto jelas merupakan bentuk tindakan menggunakan kewenang- an, program dan kegiatan pemerintah Kota Makassar untuk kepentingan pemilihan yang dilakukan dalam rentang waktu 6 (enam) bulan sebelum penetapan Pasangan Calon oleh KPU yang menguntungkan atau merugikan salah satu pasangan calon yang secara tegas dilarang oleh UndangUndang.

Berdasarkan uraian diatas, jelas bahwa penggunaan kewenangan, program dan kegiatan pembagian HP untuk Ketua RT dan Ketua RW untuk kegiatan pemilihan yang dilakukan oleh Mohammad Ramdhan Pomanto sangat menguntungkan dirinya. Bahwa apa yang dilakukan oleh Mohammad Ramdhan Pomanto sebagai Walikota Makassar atau Petahana telah merugikan Appi-Cicu, sebab pasangan Appi-Cicu harus bersaing pada ajang Pemilihan Walikota dan Wakil Walikota yang tidak mencerminkan asas keadilan sebagaimana yang diamanatkan oleh Undang-Undang, karena salah satu peserta Pemilihan yang berstatus sebagai petahana telah menyalagunakan atau memanfaatkan kewenangan, program dan kegiatan pemerintah Makassar untuk kepentingan politiknya sebagai calon Walikota Makassar tahun 2018. Terkait pembagian HP kepada RT/RW yang diduga oleh pihak penantang sebagai penyalahgunaan wewenang yang dapat merugikan pihak penantang. Merespon perihal kasus tersebut ketua Bawaslu Kota Makassar memberikan penuturannya bahwa:

"Pembagian HP ke RT/RW, pembagian $H P$ ini ada juga dalam RPJMD dalam bentuk Perda (satu perda antara tagline 
dan pembagian HP) RPJMD 2014-2019. Kalau momenklatur dalam RPJMD itu disebutkan alat komunikasi, jadi memang ada momenklaturnya yang penganggarannya itu 2016 sedangkan di unsur pasal 71 ayat 3 itu adalah pelanggaran yang enam bulan sebelum ditetapkan sebagai calon, ditetapkan itu februari berarti yah 6 bulan sekitar oktober 2017. Sedangkan pembagian HP tersebut itu penganggaran mulai dari atau perencanaannya 2014-2019, penganggarannya 2016 dan direalisasikan 2017. Jadi tidak masuk dalam kategori enam bulan. Kemudian unsur lain didalam pasal 71 ayat 3 itu disebutkan yang dapat menentukan pasangan calon tertentu. Dari pemeriksaan persidangan itu tidak ada satupun unsur atau saksi ataupun bukti yang mengarah pada Danny Pomanto ini diuntungkan karena itu di bagi ke RT/RW, pada saat dibagikan pun tidak ada bahasa bahwa harus memilih Danny, jadi kacamata kami pada saat itu melihat bahwa ini adalah program yang ditungkan kedalam perda berarti itu sudah menjadi kewajibannya pemerintah kota untuk melaksanakan, justru dia melanggar kalau dia tidak melaksanakan karena itu program 2014-2019.,"22

Berdasarkan pernyataan diatas, dapat disimpulkan bahwa pembagian HP ke RT/RW yang dilakukan oleh Danny Pomanto tidak termasuk dalam proses kampanye seperti yang di tuduhkan oleh pihak penggugat. Hanya saja pelaksanan-

\footnotetext{
${ }^{22}$ Nursari, Ketua Bawaslu Kota Makassar, wawancara pada tanggal 8 Januari 2019.
}

nya yang tidak sesuai dengan jadwal yang telah ditentukan.

\section{Pengangkatan Tenaga Kontrak Kerja Waktu Terbatas}

Bahwa dalam rentang waktu bulan Oktober dan Desember 2017, Mohammad Ramdhan Pomanto selaku Walikota Makassar/petahana telah mengangkat $2.37680^{23}$ (dua ribu tiga ratus tujuh puluh enam) orang Tenaga Kontrak Kerja Waktu Terbatas pada Dinas Pendidikan atas dasar Surat Keputusan Walikota Makassar.

Berdasarkan hal tersebut, bahwa tindakan yang dilakukan oleh Mohammad Ramdhan Pomanto dalam masa jabatannya selaku Walikota Makassar/petahana baik yang dilakukannya sendiri ataupun oleh Tim Pemenangannya atas perintahnya baik yang bersifat langsung maupun yang tidak langsung adalah merupakan tindakan menggunakan kewenagan, kegiatan, dan program pemerintah Kota Makassar dan secara nyata dilakukan untuk menguntungkan dirinya. Berangkat dari fakta diangkatnya tenaga kontrak menjadi honorer membuat pengguat semakin yakin bahwa petahana selaku peserta pemilu kembali melakukan "curi start" kampanye yang berkedok kebijakan. Olehnya, Bawaslu sebagai badan pengawas pemilu memberikan tanggapan pula bahwa:

"Pengangkatan tenaga honorer, hasil pemeriksaan dipersidangan bahwa pengangkatan tenaga honorer itu bukan

\footnotetext{
${ }^{23}$ Dikutip dari Dokumen Pengadilan Tinggi Tata Usaha Negara (PTTUN) Makassar, h.10.
} 
berasal dari pemerintah kota melainkan itu adalah hasil reses dari DPRD kota yang dimasukkan dalam RPJMD seperti dilakukan pengangkatan karena ternyata hasil reses DPRD itu melihat bahwa banyak tenaga-tenaga sukarelawan yang tenaganya sangat dibutuhkan di sekolahsekolah tetapi ijazahnya tidak seimbang dengan tenaganya sehingga DPRD kota menjadikan ini sebagai hasil reses kemudian diangkatlah tenaga honorer itu. "24

Pernyataan ketua Bawaslu diatas, menjelaskan bahwa pengangkatan tenaga kontrak menjadi honorer telah melalui proses di DPRD. Danny Pomanto selaku Walikota hanya menyetujui hasil yang telah disepakati fraksi di DPRD kota Makassar. Olehnya, pengangkatan itu tidak dilakukan serta-merta oleh Walikota yang juga sekaligus menjadi peserta pemilu. Akan tetapi, aroma politis sangat terasa karena menjelang pemilu. Sehingga persepsi dan dugaan terjadinya pelanggaran dan penyalahgunaan wewenang tertuju pada Walikota.

\section{Penggunaan Tagline "Makassar Dua} Kali Tambah Baik"

Tagline "Makassar Dua Kali Tambah Baik adalah merupakan tagline Pemerintah Kota Makassar sebagaimana tertulis jelas dalam Rencana Pembangunan Jangka Menengah Daerah (RPJMD) Kota Makassar Tahun 2014-2019. Penggunaan Tagline "Makassar Dua Kali Tambah

\footnotetext{
${ }^{24}$ Nursari, Ketua Bawaslu Kota Makassar, wawancara pada tanggal 8 Januari 2019.
}

Baik" yang dilakukan oleh Mohammad Ramdhan Pomanto dan/atau Indira Mulyasari Paramastuti Ilham baik yang dilakukan sendiri maupun yang dilakukan oleh orang lain atas nama tim sukses, tim relawan ataupun simpatisan Mohammad Ramdhan Pomanto dan Indira Mulyasari Paramastuti Ilham adalah jelas-jelas merupakan tindakan melanggar hukum, karena telah memanfaatkan dan/atau menggunakan tagline milik Pemerintah Kota Makassar secara illegal dan secara melawan hukum untuk kepentinganpolitik dan/atau untuk kepentingan pencalonannya sebagai Bakal Calon atau Walikota dan Wakil Walikota Makassar tahun 2018.

Tagline yang digunakan walikota Makassar yang juga calon walikota dinilai sebagai "alat politik" untuk kembali meraup suara di dalam kontestasi Pilwali. Laporan penggugat atas pelanggaran petahana terkait pemanfaatan wewenang. Namun dalam proses pembenaran atas kasus "Tagline" KPU tidak memiliki otoritas untuk menyelidiki kasus tersebut. Sebagaimana yang dikatakan oleh seorang komisioner KPU Makassar bahwa:

"KPU tidak dalam kapasitas untuk menyelidiki temuan pelapor itu. karena kami juga hanya mendapat laporan. Terkait kasus tersebut bawaslu yang patut dan memiliki wewenang untuk menyelidikinya., 25

Sebagaimana yang diungkapkan komisioner diatas, bahwa KPU tidak memiliki

\footnotetext{
${ }^{25}$ Andi Syaifuddin, Komisioner KPU Makassar, wawancara pada tanggal 3Desember 2018.
} 
otoritas untuk melakukan penyelidikan terkait pelanggaran yang dilakukan pihak petahana terkait penyalahgunaan wewenang. Menurut keterangan yang diberikan komisioner diatas, hanya bawaslu yang memiliki otoritas untuk melakukan penyidikan. Melanjutkan apa yang dikatakan komisioner sebelumnya, dengan memaparkan aduan pihak pelapor. Secara spesifik ketua Bawaslu Kota Makassar menjelaskan bahwa:

"Terkait dengan penggunaan Tagline Dua Kali Tambah Baik, jadi penggunaan tagline ini memang ada dalam RPJMD Kota Makassar 20142019 yang sudah disahkan dalam bentuk perda. Didalam RPJMD ini disebutkan tagline itu adalah slogan milik kota Makassar yang siapapun bisa menggunakan itu sehingga kami berpandangan bahwa penggunaan tagline itu bukan program sebagaimana yang dimaksud dalam pasal 71 ayat 3. Karena kalau kita lihat yang namanya program yang dimaksud berdasarkan keterangan beberapa ahli dia menyebutkan yang namanya program itu adalah implikasi anggarannya itu yang dimaksud dengan program sebagaimana yang dimaksud pasal 71 ayat 3 itu. Sehingga tagline ini kami anggap bahwa penggunaan tagline itu tidak melanggar karena tidak melanggar pasal 71 karena tidak ada implikasi anggarannya, maksudnya diprogramkan, dianggarkan itu baru dianggap bahwa pelanggaran pasal 71 itu. ${ }^{, 26}$

\footnotetext{
${ }^{26}$ Nursari, Ketua Bawaslu Kota Makassar, wawancara pada tanggal 8 Januari 2019.
}

Pernyataan Ketua Bawaslu diatas, secara hukum tagline tersebut tidak dianggap melanggar aturan pemilu. Apalagi memanfaatkan momentum politik tahun 2018 lalu. Karena unsur politisasi dan pencitraan yang ditujukan kepada pihak petahana yang ingin berkontestasi kembali pada 2018 lalu. membuat lawannya menjadi "panik". Sehingga mencoba menghalalkan segala cara agar sang petahana tidak kembali ke panggung kontestasi.

\section{KESIMPULAN}

Di era pasca reformasi, pemilu menawarkan pesona tersendiri. Selain karena dianggap membuka ruang bagi rakyat untuk berpartisipasi dalam kehidupan berpolitik yang formal dan memilih kepala daerah yang diinginkan dan juga akan menuntut tumbuhnya kepekaan elite politik terhadap isu yang kontekstual dan akuntabilitas atas kinerja kandidat yang terpilih oleh rakyat. Untuk mendapatkan pemimpin yang baik tentunya Komisi Pemilihan Umum (KPU) harus professional dalam melaksanakan tugasnya, seperti: Pertama, independen yang merupakan keadaan atau posisi yang tidak terikat dengan pihak manapun, tidak tidak mengusung kepentingan pihak tertentu atau organisasi tertentu. Kedua, berintegritas. Badan penyelenggara yang memiliki integritas terhadap kedudukannya sebagai tenaga professional, ia akan berupaya melaksana-kan tugasnya dengan baik. 
Kualifikasi hasil pelaksanaan tugas dan fungsi kelembagaan Komisi Pemilihan Umum (KPU) akan sangat ditentukan oleh eksistensi institusinya. Sejumlah regulasi silih berganti sudah dikeluarkan dan ditetapkan untuk mengukuhkan eksistensi penyelenggara pemilu agar dapat menjamin terwujudnya seluruh asas dalam pelaksanaan tugasnya, mulai dari asas netralitas hingga profesionalitas. Pemilu tersebut diselenggarakan oleh Komisi Pemilihan Umum (KPU) yang bersifat nasional, tetap dan mandiri. Dalam artian hal tersebut mengisyaratkan untuk para komisioner haruslah orang-orang yang tidak berkaitan dengan partai politik. Alasannya pun jelas, demi netralitas pelaksanaan pemilihan umum.

Pelaksanaan pemilu di Kota Makassar tidak terlepas keterkaitannya dengan pelaksana pemilu itu sendiri yang bersifat independen yang dalam hal ini adalah Komisi Pemilihan Umum (KPU) kota Makassar, yang berkedudukan dan mempunyai peranan sebagai penyelenggara pemilukada yang kedudukannya diatur dalam peraturan perundangundangan. Peneliti menyimpulkan bahwa terdapat 2 poin penting yang menjadi pokok bahasan dalam skripsi ini yakni: Pertama, Komisi Pemilihan Umum (KPU) Kota Makassar mempunyai tugas, wewenang, dan kewajiban untuk mengkoordinasikan, menyelenggarakan, dan mengendalikan semua tahapan pemilihan Walikota Makassar. Mulai dari proses verifikasi berkas, proses penetapan pasangan calon, diskualifikasi pasangan calon, proses pemilihan dan sampai pada proses penetapan hasil pemilihan. Dari semua tahapan yang dilaksanakan, proses tersebut disaksikan langsung oleh panwaslu dan tim dari masing-masing pasangan calon sehingga Komisi Pemilihan Umum (KPU) tidak diintervensi oleh pihak manapun karena telah melaksanakan tugas dengan baik dan tidak berpihak pada salah satu pasangan calon. Sehingga proses pemilu tersebut telah berjalan dengan lancar sesuai dengan tahapan yang telah disebutkan sebelumnya. Namun, tidak dapat dipungkiri terdapat berbagai permasalahan dan kendala selama proses tersebut berlangsung. Maka berkaitan dengan hal tersebut dalam konteks pemilihan walikota Makassar disinilah Komisi Pemilihan Umum (KPU) diuji netralitasnya, berbagai riak-riak pun tidak dapat dihindarkan karena adanya indikasi-indikasi pelanggaran yang dituduhkan kepada pasangan Danny Indira sehingga mereka didiskualifikasi sebagai pasangan calon walikota dan wakil walikota Makassar tahun 2018.

Terkait dengan diskualifikasi pasangan calon walikota dan wakil walikota Makassar Danny-Indira, KPU Kota Makassar terlihat ambigu mengambil keputusan. Hal tersebut dapat dilihat dari proses diskualifikasi yang terkesan tidak objektif. Seharusnya KPU Kota Makassar yang diwakili kelima komisioner harus menunjukkan otoritasnya sebagai pimpinan KPU dalam mempertimbangkan putusan bawaslu yang mengganggap petahana tidak menyalahgunakan wewenang. Dan tidak perlu menanggapi putusan 
PTTUN yang tidak memiliki otoritas mengatur jalannya kepemiluaan. Sehingga KPU tidak perlu mengajukan kasasi ke Mahkamah Agung. Proses okum itulah yang menyebabkan kegaduhan di akar rumput (masyarakat) tidak terelahkan. Dan dari sisi ekonomisnya KPU telah menghabiskan dana APBD sebesar 60 miliar secara percuma. Dan pertimbangan yang fundamental pasca terjadinya diskualifikasi tersebut ternyata tidak juga menghasilkan pemimpin baru di Kota Makassar karena dimenangkan oleh kotak kosong. Sebagai bukti nyata bahwa masyarakat kecewa terhadap putusan KPU yang mendiskualifikasi petahana.Sehingga Makassar harus menunggu tahun 2020 untuk kembali menyelenggarakan kontestasi kembali

$* * *$

\section{DAFTAR PUSTAKA}

Edward Aspinall \& Mada Sukmajati, Politik Uang di Indonesia, (Yogyakarta: Polgov, 2015).

Irvan Januta, "Teori Strukturasi Anthony Giddens", Tesis (Yogyakarta: UIN Sunan Kalijaga, 2003).

Kementerian Agama, Al-Qur"an Tajwid dan Terjemahanya, (Bandung: Syaamil AlQurean, 2010).

Mohammad Najib, Keterlibatan Penyelenggara Pemilu dalam Vote Trading, (Yogyakarta: Polgov, 2015).

Muslim Mufti, Teori-Teori Politik, (Bandung: Pustaka Setia, 2012).
Pip Jones, Pengantar Teori-Teori Sosial dari Teori Fungsionalisme hingga Post Modernism, (Jakarta: Yayasan Pustaka Obor Indonesia, 2009).

Ridwan, Jayapura Utara, Papua: Membeli Pemilih dan Penyelenggara Pemilu, (Yogyakarta: Polgov, 2015).

Rozali Abdullah, Mewujudkan Pemilu Yang Lebih Berkualitas, (Jakarta: PT RajaGrafindo Persada, 2009).

Sukmadinata, Metode Penelitian, (Bandung: Rosdakarya, 2006).

Syahabuddin, "Demokrasi dalam Pandangan Abdul Kahar Muzakkar", Program Pasca Sarjana UIN Sunan Kalijaga, Disertasi (Yogyakarta: Program Pascasarjana UIN Sunan Kalijaga, 2006).

Syahrul Hidayat, Rasionalitas Politik Pemilih Miskin: Dari Survey di Jakarta dan Surabaya, (Jakarta: FISIP UI, 2000).

Tengku Rika Valentina, "Peluang Demokrasi dan Peta Perilaku Pemilih Terhadap Partai Politikuntuk Pemilu 2009 di Yogyakarta", Jurnal: Demokrasi, Vol. VIII No. 2 (2009), h. 167-186.

\section{Wawancara}

Abdullah Mansur, Komisioner KPU Makassar, wawancara pada tanggal 29 Oktober 2018. 
Andi Syaifuddin, Komisioner KPU Makassar, wawancara pada tanggal 3 Desember 2018.

Nursari, Ketua Bawaslu Kota Makassar, wawancara pada tanggal 8 Januari 2019. 